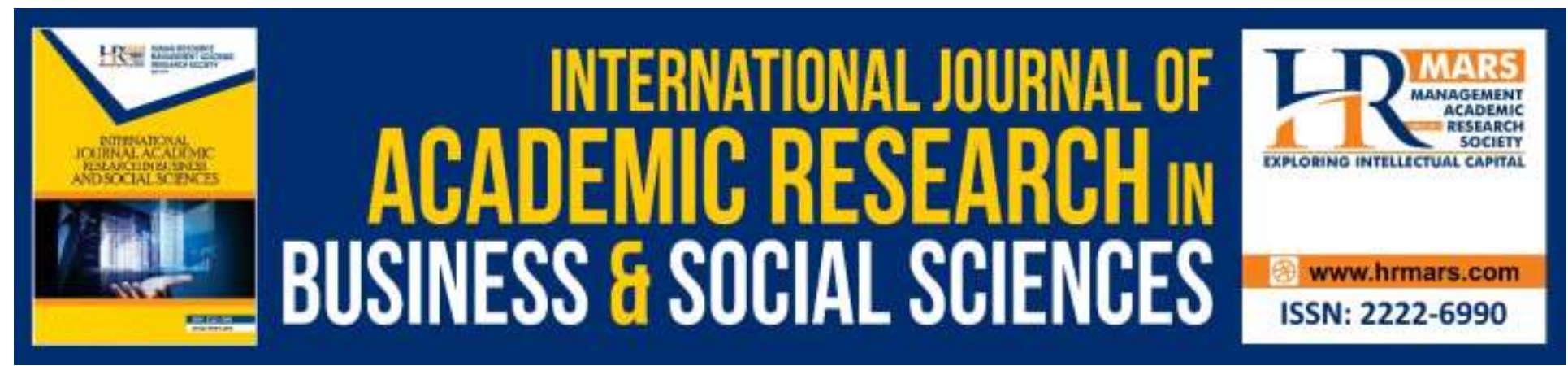

\title{
Green Marketing and Perceived Corporate Image: A Study of Fast Moving Consumer Goods in Lagos State Nigeria
}

\author{
AYO Mofoluwake Folasayo
}

To Link this Article: http://dx.doi.org/10.6007/IJARBSS/v9-i7/6110

DOI: $10.6007 /$ IJARBSS/v9-i7/6110

Received: 14 May 2019, Revised: 23 June 2019, Accepted: 01 July 2019

Published Online: 24 July 2019

In-Text Citation: (Folasayo, 2019)

To Cite this Article: Folasayo, A. M. (2019). Green Marketing and Perceived Corporate Image: A Study of Fast Moving Consumer Goods in Lagos State Nigeria. International Journal of Academic Research in Business and Social Sciences, 9(7), 202-224.

\section{Copyright: (C) 2019 The Author(s)}

Published by Human Resource Management Academic Research Society (www.hrmars.com)

This article is published under the Creative Commons Attribution (CC BY 4.0) license. Anyone may reproduce, distribute, translate and create derivative works of this article (for both commercial and non-commercial purposes), subject to full attribution to the original publication and authors. The full terms of this license may be seen

at: http://creativecommons.org/licences/by/4.0/legalcode

Vol. 9, No. 7, 2019, Pg. 202 - 224

http://hrmars.com/index.php/pages/detail/IJARBSS

JOURNAL HOMEPAGE

Full Terms \& Conditions of access and use can be found at http://hrmars.com/index.php/pages/detail/publication-ethics 


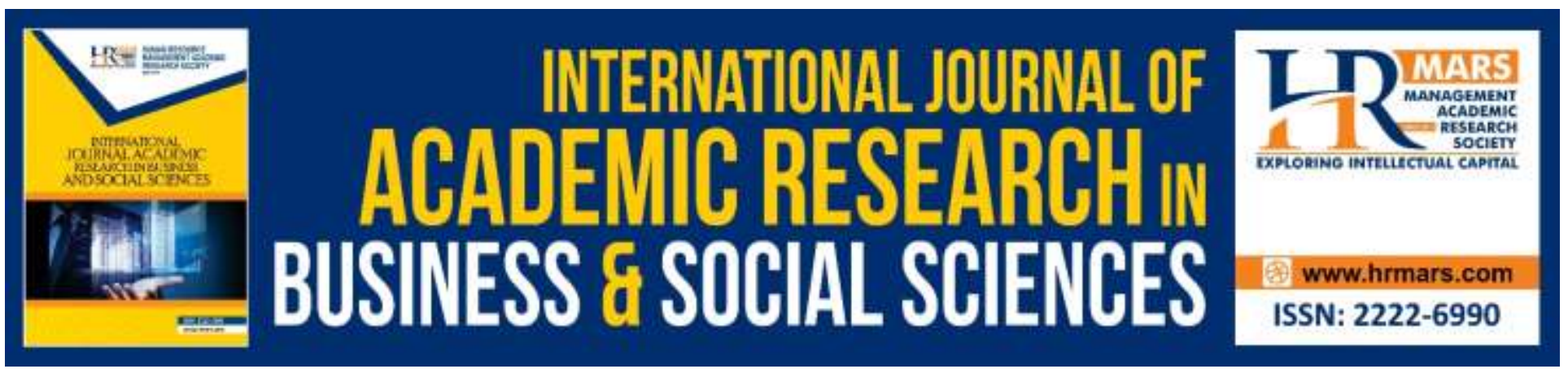

\title{
Green Marketing and Perceived Corporate Image: A Study of Fast Moving Consumer Goods in Lagos State Nigeria
}

\author{
AYO Mofoluwake Folasayo \\ Department of Management and Accounting, Lead City University, Nigeria \\ Email: ayomofoluwake@yahoo.com
}

\begin{abstract}
There is a worldwide accord that pressing changes in human conduct and social practices are required. Consumers are increasingly becoming aware on matters such as environmental disaster, climate change, economic instability, and societal issues. This scenario has created opportunities for some organisations to stand out and achieve competitive advantage. The trend of sustainable purchase and consumption has not fully spread to Nigeria, as many of the Nigerian consumers are yet to familiarise themselves with sustainability and green issues. The study examines the influence of green marketing on perceived corporate image. Drawing on a sample of consumers working in different sectors of the economy in Lagos state, 898 copies of the questionnaire were distributed. The study found that green marketing significantly affects perceived corporate image of fast moving consumer goods.
\end{abstract}

Keywords: Green Marketing, Corporate Image, FMCG

\section{Introduction}

Globally, consumers are increasingly becoming aware and enabled by the rising surge in information technology (internet) and the social media on matters such as environmental disaster, climate change, economic instability, and societal issues. This scenario has created opportunities for some organisations to stand out and achieve competitive advantage through constantly balancing their primary mission against societal considerations (Rizkallah, 2012). Kostadinova (2016), observed that over the last couple of decades, consumption has expanded to uncommon levels around the world, prompting exhaustion of natural resources, loss of biodiversity and fast natural decay. The author further stated that people are now consuming 30\% more resources every year than the planet could recover and this pace is quickening. There is a worldwide accord that pressing changes in human conduct and social practices are required keeping in mind the end goal to lessen the impacts of overconsumption. People are more mindful that the period of undisturbed consumerism is coming 
to an end and that their individual practices directly affect the environment and the lives of the present and future generations. Consumers are now conscious of their roles and significance in the society, and they are beginning to take actions that would positively impact their environment and their welfare eventually. This has led to an increasing demand for environmentally nontoxic goods (Ali \& Ahmad, 2012; Chen, 2010; Rashid, 2009). The shifting attitudes of consumers regarding healthy consumption, protection of the environment and social responsibility has forced companies into looking for new choices of activities in which societal concerns would be integrated (Banyte, Brazioniene \& Gadeikiene, 2010).

Presently, the business values of going green and being eco-friendly are prevalent, with organizations creating marketing agendas that emphasize on favorable responses to such views. However, it should be noted that this has not always been the case. Although, sustainable consumption came to limelight in the academics in the late 1960's, the term, 'green marketing' was not celebrated until the late 80's and mostly the 90's, a period that experienced a rise in eco-labelling (D'Souza, Tagian, Lamb, \& Peretiatk, 2007; Horne, 2009). According to Kumar (2011), there is a drastic increase in ecological awareness globally which has been spurred by the advent of green marketing. Green marketing reported over 200 USD billion market of lifestyle of Health and Sustainability (LOHAS) in 2010 and was expected to rise four times bigger by 2015 (Widger, 2007).

It has been shown that the quest for socially responsible products has continually grown in developed countries (Greendex, 2012; Synovate, 2011). Consumers in developed countries are not only interested in satisfying their own needs, but they are striving to ensure a sustainable environment and society. These consumers could even go as far as shunning products or brands that do not meet societal expectations (Belz \& Peattie, 2009; Harrison, Newholm \& Shaw, 2005; Sheikh \& Zee, 2011). The issue of global warming and the exhaustion of resources are some of the major fears the world is facing (Steffen \& Gunther, 2013). According to the UN Global Compact-Accenture's CEO study (2010), ninety-three percent (93\%) of the 766 CEOs that were surveyed from all over the world, affirmed sustainability as a an important factor for the future success of their organisations. In fact, eighty-one percent (81\%) of the CEOs indicated that sustainability issues have been optimally embedded into the strategy and operations of their organisations. The increasing emphasis placed by firms on ethical and socially driven activities have primarily shifted the way individuals think about and understand the relationship between firms, their environment and stakeholders, such as suppliers, communities, employees, consumers and global society (loannou \& Serafeim, 2010). In the United Kingdom for example, there has been a shift in the notion of a company's purpose to an enlightened shareholder value. Companies in the United Kingdom are required to make a social report on the impact of their operations on the society; suppliers, consumers, employees and the environment inclusive (Amaeshi, Adi, Ogbechie \& Amao, 2006).

From a pilot study carried out by the researcher, some gaps in literature were identified. Prominent is the need to incorporate the concept of environmental knowledge and consumer understanding of what is 'green' (Arminda do Paço, Alves, Shiel \& Filho, 2013; Dutta, 2014; Rettie, Burchell \& Barnham, 2013). Also there is need to incorporate more emphasis on what consumers actually do rather than plan to do, thus helping to avoid the common attitude-behaviour pitfalls identified in many previous studies (McEachern \& Carrigan, 2012). Further study is needed to examine consumption in developing countries because it is tied into the wider realm of geopolitical fairness between 
INTERNATIONAL JOURNAL OF ACADEMIC RESEARCH IN BUSINESS AND SOCIAL SCIENCES

Vol. 9, No. 7, July, 2019, E-ISSN: 2222-6990 @ 2019 HRMARS

developed and developing countries (Prothero, Dobscha, Freund, Kilbourne, Luchs, Ozanne \& Thøgersen, 2011).

\section{Research Problem}

Globally, the challenges of increased awareness and need for sustainable consumption have plagued the fast moving consumer goods industry, as consumers are beginning to connect their nutrition and quality of food purchased to their daily lifestyle. (Ali \& Ahmad, 2012; Chen, 2010; Finisterra do Paco \& Raposo, 2009; Rashid, 2009). The trend of sustainable purchase and consumption has not fully spread to Nigeria, as many of the Nigerian consumers are yet to familiarise themselves with sustainability and green issues (Quick pulse, 2011; Olamuyi, 2012). Though there is an increasing environmental and green marketing awareness globally, it has been shown that merely about $5 \%$ of the Nigerian population is involved in sustainable purchase behavior (Karatu \& Mat, 2015). Although ecological factor is a key consumer issue, with 59 percent of consumers concerned worldwide, this is not reflected in consumer behavior (Retie, Burchell \& Barnham, 2013).

There has been a disappointing performance of green marketing initiatives (Retie, Burchell \& Barnham, 2013). While previous study have shown that there is an extensive 'green market' potential among consumers in developed countries, unfortunately, this seemingly widespread consumer interest in socially responsible product is not reflected in consumer behavior or market shares (Davis, 2013). The emergence of green marketing in the 1990s promised a 'green revolution' in marketing. However, despite some signs of good practices, environmental marketing has not shown the expected results in terms of real changes in behaviors (Zabkar \& Hosta, 2013). Nigeria is still much backward on green issues as depicted by the extremely low percentage (5\%) of green product purchase (Ajike, 2015; Karatu \& Mat, 2015; Olamuyi, 2012; Quick Pulse survey, 2011) which has been attributed to the absence of environmental consciousness among Nigerian citizens (Karatu \& Mat, 2015). In addition, it has been indicated that $28.1 \%$ of individuals are disposed to participating in programmes initiated with the objective of decreasing environmental deterioration in Nigeria (Ohakwe, Nnorom \& Iwueze, 2011). According to the National Bureau of Statistics (2012), 44.9\% of households in Nigeria dump their refuse in unauthorised refuse heaps. According to Fagbohun (2012), this poses a threat to the security of a country. The author further revealed that national security has gone beyond fighting forces and has extended to issues such as bio-diversity and pollution which could be land, water or air. While many companies are increasing their efforts to have sustainable operations and offer environmentally preferable products, consumers are often unaware of the environmental benefits because the companies are not communicating in ways that are compatible with the consumer's schema regarding environmental issues thereby leading to discouraging consumer response (Smith \& Brower, 2012).

\section{Research Hypothesis}

Fombrun, Gardberg and Barnett (2000), observed that although corporate social and environmental performance may not directly affect a company's financial performance, it significantly affects the organisation's reputational capital, which is the financial value of its intangible assets. Organisations believe that when they engage in environmental responsibility, their reputation could alleviate the negative emotions from their stakeholders when faced with damaging information (Eisingerich \& 
Bhardwaj, 2011). Also, the study of D'Souza, Taghian and Sullivan-Mort (2013), showed that green marketing which involved creating green awareness, promoting environmental components of the product and fulfiling green marketing needs emerged as a more dominant variable that affects corporate reputation. Rambalak, Abhishek and Govind (2016), found that eco-friendly activities has a significant influence on the corporate image of an organization, which then leads to a significant positive impact on the consumer's intention to purchase from such organizations. Eunju, Kyung and Young (2013), in their study explored the relationship between green marketing, corporate image, and purchase intentions in the retail setting from a consumer perspective. The researchers found that corporate image consist of three factors: corporate reputation, social responsibility and product image. In addition, it was found that green marketing has a direct effect on the product image.

However, Davis (2013), found that majority of consumers prioritise conventional product features and demonstrate low interest in socially responsible products. D'Souza, Taghian, and Sullivan-Mort (2013), carried out a research on environmentally motivated actions influencing perceptions of environmental corporate reputation. The study findings indicate that while environmental processes are substantially important to a firm, such processes do not have a significant influence on corporate reputation. Nyilasy, Gangadharbatla and Paladino (2014), found that the negative effect of a firm's low environmental performance on brand attitudes is higher when the same organization engages in green advertising compared to the general corporate advertising and no advertising. In addition, the study findings indicate that when a firm's environmental performance is high, the green and general corporate advertising would result in negative brand attitudes than no advertising.

\section{Therefore, it is Hypothesized that: Green Marketing has no Significant Effect on Corporate Image.}

\section{Literature Review}

According to the American Marketing Association, green marketing is the marketing of products that are assumed to be environmentally safe. It includes a wide range of activities, such as product modification, production process change, advertising message modification, product package modification (Padhy, 2014). The term green marketing which started in the late 1980s and early 1990s began in Europe when some products were found to be unsafe to the environment and society in general. Thus, new varieties of products known as the green products were produced. It was believed that these products would cause less damage to the environment (Singh, 2012). Green marketing sometimes referred to as environmental or eco-marketing, is a relatively new marketing strategy with the aim of developing existing marketing approach by providing a significantly different perspective. Green marketing seeks to address the misfit between fundamental marketing practices and current ecological and social realities in the broader marketing environment (Banerjee, 2013). According to Verma and Tanwar (2014), green marketing consists of all marketing actions aimed at generating and facilitating exchanges intended to satisfy consumer needs or wants, in a way that the satisfaction of these needs and wants occurs, with little to no harmful effect on the environment.

Green Marketing is the path toward changing the inside estimations of an organisation's business with customers and in addition with those of its staff to encourage a more capable administration. Green Marketing outline should join all stakeholders and grasps a mutual method to manage the introduction of new initiatives (Kumar \& Shree, 2018). Green marketing consolidates an expansive 
scope of exercises, including product and production process modification, changes in product packaging, as well as advertising and communication modification. However, defining green marketing is not a basic assignment where a few implications converge and repudiate each other; a case of this would be the presence of differing social, natural and retail definitions joined to this term. Other comparative terms utilised are environmental marketing and ecological marketing (Mayank, 2017). Green consumption is an effective way to limit the hostile effect of consumption on nature (Rambalak \& Govind, 2017).

As lifestyle and consumption patterns of consumers have been described as the foremost originator of environmental issues, the role of marketing has become pertinent. Explaining further, while marketing has been criticised on one hand as being a major contributor to environmental damage by focusing on short-term satisfaction of consumers, it is on the other hand, seen as a significant instrument in promoting new lifestyles and helping to change the overall consumption habits of all consumers (Maheshwari, 2014). Organisations around the globe adopt green practices with the expectation of decreasing their ecological effects and enhance their performance financially (Miroshnychenko, Barontini \& Testa, 2017).

For organizations, it is believed that green marketing is an opportunity they can use to achieve their objectives. Organizations have observed that in adopting green marketing, they will be reducing their waste which will lead to a reduction the amount of raw material needed and which in the long run would reduce cost and increase profit for the organization. Also, organizations have a moral obligation to be more socially responsible. They now see themselves as part of a larger community and must therefore carry out their activities in a way that is environmentally safe. This can be credited to increasing pressure from government, consumers and even competitors for organizations to adopt green marketing. The government is saddled with the responsibility of protecting the consumers and society at large. Some of the government regulations aimed at ensuring green marketing are, decreasing the production of unsafe goods or byproducts and ensuring that every consumer has the ability to assess the environmental composition of all goods and services. There is a growing interest among the consumers all over the world regarding protection of environment. Research globally has indicated that consumers are now more concerned about the environment (Tiwarii, Tripathi, Srivastava \& Yadav, 2011).

\section{Review of Relevant Theories Legitimacy Theory}

According to the Legitimacy theory which is central to the social contract (implicit or explicit), firms have a contract with the society as a whole (Dowling \& Pfeffer 1975; Mathews, 1993). This social contract is conveyed via the expectations of the society. These expectations are not fixed, thereby changing over time (Islam and Craig 2008). Every organisation has a moral obligation to meet the expectations of the societal members. When a company satisfies the expectations of the society, it would be viewed and treated as legitimate and vice versa (Deegan \& Jeffry, 2006).

According to Deegan and Jeffry (2006), only a company that is viewed as legitimate has the right to employ the society's human and natural resources. Therefore, organizations are mandated to respond to the varying expectations of the society so as to be able to maintain their legitimacy (Islam \& Craig 2008). Seele and Gatti (2017), combined signaling theory with legitimacy theory to frame the 
communication process of the greenwashing accusation and the emergence of a negative narrative caused by the accusation and its effect on legitimacy. Based on the researchers' conceptual analysis, they were able to provide a conceptual framework presenting a new typology of case-based greenwashing (greenwashing, potential greenwashing, false greenwashing and no greenwashing) and their influence on corporate legitimacy. Leonidou, Leonidou, Hadjimarcou and Lytovchenko (2014), adopted the legitimacy theory to develop and test hypotheses linking various dimensions of environmental claims made in green advertisements with advertising greenness. The researchers carried out a content analysis of 383 green magazine advertisements and found that in consensus with legitimacy theory, the stronger the advertisement greenness, the more acceptable are the issues raised.

Using an integrated theoretical framework to explain corporate social responsibility (CSR) practices by organizations, Fernando and Lawrence (2014), adopted three theories, namely legitimacy theory, stakeholder theory and institutional theory. The authors noted that all three theories are very relevant and have been used extensively in CSR literature. By means of legitimacy theory, Bhattacharyya (2015), sheds more light on the issue of corporate social responsibility in emerging economies. The researcher carried out a survey of the attitudes of Indian managers, toward 18 social and 16 contemporary environmental issues. The study findings indicate that respondents are concerned about issues on social responsibility and are in strong support of environmental responsibilities.

Consumers and other stakeholders expect organizations to consider the societal implications of their activities. According to the theory, when organizations ensure that their activities do not have adverse effect on the consumers, environment and the society at large, they are viewed by the consumers as being legitimate. The consumers in turn respond positively towards the company brand and product. Such response can be in form of product purchase, brand loyalty or positive perception of the company's image.

\section{Institutional Theory}

The institutional theory is a theoretical framework used to analyze social phenomena. The theory views the social world as considerably consist of institutions (rules, practices, and structures) that set conditions on action. In order to adequately explain the social world, institutions are vital. This is because they are built into the social order and also direct the flow of social life (Lawrence \& Shadnam, 2008). Institutional theory, which originated in organisational studies, incorporates both classical and pluralist views of the political economy theory (Yang, 2014). According to Dillard, Rigsby and Goodman (2004), the main focus of the theory is on the interaction of an organization with its economic and political institutional environment. The theory also focuses on how institutional pressures influence the organization, and how these expectations are incorporated into the practices and characteristics of an organization. Institutional theory takes into consideration the procedures by which cultural, regulative and normative reasoning structures are recognized as the standard for social behavior (Scott, 2008), where consideration for social and environmental implications of an organizations activities is a part. Institutional theory generally states that a firm's behavior is governed by its institutional environment. This institutional environment is made up of the organizations activities, its social context and its web of social relationships (Doshi \& Khokle, 2012). 
According to the institutional theory, an increasing number of stringent global environmental guidelines have been developed. There has also been an increasing environmental consciousness among consumers, implying that organizations must change their patterns in business and marketing activities (Chen \&Lin, 2010). Institutional theory has also been used to study the inspirations behind corporate social and environmental reporting practices (Islam \& Craig 2008), explain the role of the government in social and environmental disclosure (Amran \& Susela, 2008), explain corporate social and environmental disclosure (CSED) practices of the companies in developing countries (Ali \& Rizwan, 2013). In the area of corporate social responsibility, institutional pressures have not only been found to drive corporate social responsibility (CSR) spending but also influence its policy (Avetisyan \& Ferrary, 2013; Dash \& Mishra, 2015). According to Bondy, Moon and Matten (2012), institutional mechanisms, most importantly, the coercive and normative mechanisms, have led to the institutionalisation of corporate social responsibility practices. Although, sustainability reporting guidelines and standard are largely voluntary, many organisations are increasingly faced with societal pressures to embrace and adopt such guidelines (Eccles \& Saltzman, 2011; Vigneau, Humphreys, \& Moon, 2015). Guo, Tao, Li and Wang (2017), adopted the institutional theory to explain the concept of green-washing. The authors shed light on green promise and green trust among Chinese energy companies. Using a survey data, the authors found that green promise not only has a direct negative effect on green trust but also has an indirect influence through the mediating role of green energy brand legitimacy. Other authors that have adopted the institutional theory to explain sustainable purchasing practices include, Adebanjo, Ojadi, Laosirihongthing \& Tickle, (2013); Blome \& Hollos, (2014); Carbone \& Moatti, (2011); Czinkota, Kaufmann \& Basile, (2014); Lee \& Rha, (2013); Snider, Halpern, Rendona, \& Kidalov, (2013).

Table 1: Review of Past Empirical Literature on Green marketing

\begin{tabular}{|c|c|c|c|}
\hline SN & Author(s) & Title & Findings \\
\hline 1 & $\begin{array}{l}\text { Grimmer, M. \& } \\
\text { Woolley, M. } \\
(2014)\end{array}$ & $\begin{array}{l}\text { Green marketing messages } \\
\text { and consumers' purchase } \\
\text { intentions: Promoting } \\
\text { personal versus } \\
\text { environmental benefits }\end{array}$ & $\begin{array}{l}\text { The study shows that consumers' level } \\
\text { of environmental affect influences how } \\
\text { they respond to marketing } \\
\text { communications that promote different } \\
\text { environmental messages. Those with } \\
\text { higher level of affect were more likely to } \\
\text { be swayed by a pure environmental } \\
\text { advertisement; those with a lower level } \\
\text { of affect were more likely to be swayed } \\
\text { by a personal environmental } \\
\text { advertisement. }\end{array}$ \\
\hline 2 & 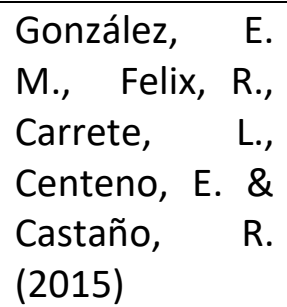 & $\begin{array}{l}\text { Green shades: a } \\
\text { segmentation approach } \\
\text { based on ecological } \\
\text { consumer behaviour in an } \\
\text { emerging economy AN }\end{array}$ & $\begin{array}{l}\text { The findings suggest that marketing } \\
\text { managers and policymakers should } \\
\text { consider different combinations of } \\
\text { ecological behaviours and include } \\
\text { demographic and attitudinal variables, } \\
\text { such as perceived consumer }\end{array}$ \\
\hline
\end{tabular}




\begin{tabular}{|c|c|c|c|}
\hline & & & $\begin{array}{l}\text { effectiveness and environmental and } \\
\text { social values, rather than only focusing } \\
\text { on high or low adoption levels of pro- } \\
\text { environmental behaviours in general. }\end{array}$ \\
\hline 3 & Dutta, S. (2014) & $\begin{array}{l}\text { Components of ecological } \\
\text { behaviour and consumer } \\
\text { attitude } \quad \text { towards } \\
\text { sustainable green } \\
\text { environment: An empirical } \\
\text { analysis on Kolkata citizens }\end{array}$ & $\begin{array}{l}\text { The study reveals that environmental } \\
\text { attitudes of the citizen have a } \\
\text { substantial impact on ecological } \\
\text { behaviour and actual commitment to } \\
\text { address the long term environmental } \\
\text { sustainability }\end{array}$ \\
\hline 4 & $\begin{array}{lr}\text { Rettie, } & \text { R., } \\
\text { Burchell, K. } & \& \\
\text { Barnham, } & \text { C. } \\
(2013) & \end{array}$ & $\begin{array}{l}\text { Social normalisation: using } \\
\text { marketing to make green } \\
\text { normal }\end{array}$ & $\begin{array}{l}\text { The study found that consumers are } \\
\text { more likely to adopt behaviour and } \\
\text { products that they think are normal and } \\
\text { that what is regarded as normal changes } \\
\text { over time. The new activities and } \\
\text { products that are initially seen as } \\
\text { different, and as outside normal } \\
\text { behaviour, can eventually become } \\
\text { mainstream and accepted as normal, in } \\
\text { a process of 'social normalisation'. }\end{array}$ \\
\hline 5 & $\begin{array}{l}\text { Matthes, J. \& } \\
\text { Wonneberger, } \\
\text { A. (2014) }\end{array}$ & $\begin{array}{l}\text { The skeptical green } \\
\text { consumer revisited: testing } \\
\text { the relationship between } \\
\text { green consumerism and } \\
\text { skepticism toward } \\
\text { advertising }\end{array}$ & $\begin{array}{l}\text { The study shows no positive relationship } \\
\text { between green consumerism and } \\
\text { general ad skepticism. However, green } \\
\text { consumerism was negatively related to } \\
\text { green advertising skepticism. Green } \\
\text { consumers saw more informational } \\
\text { utility in green ads than non-green } \\
\text { consumers did. }\end{array}$ \\
\hline 6 & $\begin{array}{l}\text { Karmarkar, U. } \\
\text { R. \& Bollinger, } \\
\text { B. (2015) }\end{array}$ & $\begin{array}{l}\text { BYOB: how bringing your } \\
\text { own shopping bags leads to } \\
\text { treating yourself and the } \\
\text { environment }\end{array}$ & $\begin{array}{l}\text { The study indicates that the single act of } \\
\text { bringing one's bags can increase } \\
\text { purchases of organic and indulgent } \\
\text { foods in parallel through separable } \\
\text { mechanisms. }\end{array}$ \\
\hline 7 & $\begin{array}{l}\text { Paço, A., Alves, } \\
\text { H., Shiel, C. \& } \\
\text { Filho, L. (2013) }\end{array}$ & $\begin{array}{l}\text { Development of a green } \\
\text { consumer behaviour model }\end{array}$ & $\begin{array}{l}\text { The results indicate that there is a } \\
\text { relationship between values and } \\
\text { attitudes, and between attitudes and } \\
\text { behaviour }\end{array}$ \\
\hline 8 & $\begin{array}{lll}\text { Green, } & \text { T. } & \& \\
\text { Peloza, } & & \text { J. } \\
(2014) & & \\
\end{array}$ & $\begin{array}{l}\text { Finding the right shade of } \\
\text { green: the effect of } \\
\text { advertising appeal type on } \\
\text { environmentally friendly } \\
\text { consumption }\end{array}$ & $\begin{array}{l}\text { The results of the study indicate that in } \\
\text { contexts where consumers experience } \\
\text { heightened public accountability they } \\
\text { are more responsive to other benefit }\end{array}$ \\
\hline
\end{tabular}


INTERNATIONAL JOURNAL OF ACADEMIC RESEARCH IN BUSINESS AND SOCIAL SCIENCES

Vol. 9, No. 7, July, 2019, E-ISSN: 2222-6990 @ 2019 HRMARS

\begin{tabular}{|c|c|c|c|}
\hline & & & $\begin{array}{l}\text { appeals, and in more private settings } \\
\text { they favour self-benefit appeals }\end{array}$ \\
\hline 9 & $\begin{array}{l}\text { McEachern \& } \\
\text { Carrigan (2012) }\end{array}$ & $\begin{array}{l}\text { Revisiting contemporary } \\
\text { issues in green/ethical } \\
\text { marketing: An introduction } \\
\text { to the special issue }\end{array}$ & $\begin{array}{l}\text { The review concludes that there is need } \\
\text { for researchers to incorporate the } \\
\text { context of the individual but } \\
\text { simultaneously acknowledge the } \\
\text { irrationality often underpinning } \\
\text { consumption decisions. }\end{array}$ \\
\hline 10 & $\begin{array}{l}\text { Moraes, C., } \\
\text { Carrigan, M. \& } \\
\text { Szmigin, } \quad \text { I. } \\
(2012)\end{array}$ & $\begin{array}{l}\text { The coherence of } \\
\text { inconsistencies: Attitude- } \\
\text { behaviour gaps and new } \\
\text { consumption communities }\end{array}$ & $\begin{array}{l}\text { The study showed that structural } \\
\text { interventions (even small-scale ones) } \\
\text { can reconnect individuals through their } \\
\text { wider social processes to embed } \\
\text { sustainable practices into everyday life. } \\
\text { Also, connections to wider society }\end{array}$ \\
\hline 11 & $\begin{array}{ll}\text { Scott, L. } & \& \\
\text { Vigar-Ellis, } & \text { D. } \\
(2014) & \end{array}$ & $\begin{array}{l}\text { Consumer understanding, } \\
\text { perceptions and } \\
\text { behaviours with regard to } \\
\text { environmentally friendly } \\
\text { packaging in a developing } \\
\text { nation }\end{array}$ & $\begin{array}{l}\text { The study found that there is limited } \\
\text { promotion or implementation of } \\
\text { environmentally responsible practices } \\
\text { by authorities or industry. South African } \\
\text { consumers in this study were found to } \\
\text { exhibit limited knowledge of what } \\
\text { environmentally friendly packaging is } \\
\text { and how to differentiate it from normal } \\
\text { packaging, as well as its benefits. }\end{array}$ \\
\hline 12 & $\begin{array}{l}\text { Leonidou, L. C., } \\
\text { Leonidou, C. N. } \\
\text { \& Kvasova, O. } \\
(2010)\end{array}$ & $\begin{array}{l}\text { Antecedents and outcomes } \\
\text { of consumer } \\
\text { environmentally friendly } \\
\text { attitudes and behaviour }\end{array}$ & $\begin{array}{l}\text { The study found that both the inward } \\
\text { and outward environmental attitudes of } \\
\text { a consumer are positively influenced by } \\
\text { his/her degree of collectivism, long-term } \\
\text { orientation, political involvement, } \\
\text { deontology, and law obedience, but } \\
\text { have no connection with liberalism. The } \\
\text { adoption of an inward environmental } \\
\text { attitude was also found to be conducive } \\
\text { to green purchasing behaviour that } \\
\text { ultimately leads to high product } \\
\text { satisfaction. }\end{array}$ \\
\hline 13 & $\begin{array}{l}\text { Trivedi, R. H., } \\
\text { Patel, J. D. \& } \\
\text { Savalia, J. R. } \\
\text { (2012) }\end{array}$ & $\begin{array}{l}\text { Pro-environmental } \\
\text { Behaviour of Consumers: A } \\
\text { Taxonomy and Its } \\
\text { Implications for the Green } \\
\text { Marketer }\end{array}$ & $\begin{array}{l}\text { The study showed that there are three } \\
\text { categories of pro environmental } \\
\text { behavioural motives. They are; Energy } \\
\text { Economist, Energy Conservatist and } \\
\text { Environmental Activist }\end{array}$ \\
\hline
\end{tabular}




\begin{tabular}{|c|c|c|c|}
\hline 14 & $\begin{array}{lll}\text { Smith, } & \text { K. } & \& \\
\text { Brower, } & \text { T. } & \text { R. } \\
(2012) & & \end{array}$ & $\begin{array}{l}\text { Longitudinal study of green } \\
\text { marketing strategies that } \\
\text { influence Millennials }\end{array}$ & $\begin{array}{l}\text { Results indicate that millennials are } \\
\text { taking note of a company's reputation, } \\
\text { reading product labels, and looking for } \\
\text { clues on product packaging to discern if } \\
\text { a product is environmentally preferable. } \\
\text { Specific symbols and terms are } \\
\text { identified as being effective in conveying } \\
\text { the green message. they are eco- } \\
\text { friendly, recycled, and green }\end{array}$ \\
\hline 15 & $\begin{array}{l}\text { Kronrod, } \quad \text { A., } \\
\text { Grinstein, } \\
\text { Wathieu, \& } \\
(2012)\end{array}$ & $\begin{array}{l}\text { Go green! Should } \\
\text { environmental messages } \\
\text { be so assertive? }\end{array}$ & $\begin{array}{l}\text { The findings indicate that when message } \\
\text { receivers perceive an issue as important, } \\
\text { they are affected more by assertive than } \\
\text { nonassertive phrasing and are more } \\
\text { willing to comply with the message. This } \\
\text { suggests that compliance with and } \\
\text { expectations for more assertive } \\
\text { language occur when the message is in } \\
\text { line with the recipient's perceived } \\
\text { importance of the issue. }\end{array}$ \\
\hline 16 & $\begin{array}{lrr}\text { Zabkar, } & \text { V. } & \& \\
\text { Hosta, } & & \text { M } \\
(2013) & & \end{array}$ & $\begin{array}{l}\text { Willingness to act and } \\
\text { environmentally conscious } \\
\text { consumer behaviour: can } \\
\text { prosocial status } \\
\text { perceptions help overcome } \\
\text { the gap? }\end{array}$ & $\begin{array}{l}\text { The study found that 'pro-social status' } \\
\text { perceptions increase the positive } \\
\text { association between 'willingness' and } \\
\text { 'behaviour' and could be incorporated } \\
\text { into green products and advertising to } \\
\text { signal personality traits like kindness and } \\
\text { intelligence. Also, it was found that } \\
\text { women have a higher average } \\
\text { representation in groups of people with } \\
\text { high pro-social status perceptions. }\end{array}$ \\
\hline 17 & $\begin{array}{ll}\text { Davari, A. } & \& \\
\text { Strutton, } & \text { D. } \\
(2014) & \end{array}$ & $\begin{array}{l}\text { Marketing mix strategies } \\
\text { for closing the gap between } \\
\text { green consumers' pro- } \\
\text { environmental beliefs and } \\
\text { behaviours }\end{array}$ & $\begin{array}{l}\text { The results indicated that all four } \\
\text { elements of green marketing strategy } \\
\text { were related to brand loyalty. Green } \\
\text { product and green place each had } \\
\text { positive influence on PBQ; price and } \\
\text { promotion were not related. By } \\
\text { contrast, green product and green price } \\
\text { were the only two elements of } \\
\text { marketing mix that are related to brand } \\
\text { trust. Apparently, green product is the } \\
\text { only marketing mix element that is } \\
\text { capable of exercising a positive influence } \\
\text { on each dimension of brand equity. }\end{array}$ \\
\hline
\end{tabular}




\begin{tabular}{|c|c|c|c|}
\hline 18 & $\begin{array}{l}\text { Fuentes, C. } \\
(2014)\end{array}$ & $\begin{array}{l}\text { Managing green } \\
\text { complexities: consumers' } \\
\text { strategies and techniques } \\
\text { for greener shopping }\end{array}$ & $\begin{array}{l}\text { The study shows that consumers have } \\
\text { different strategies and techniques to } \\
\text { make their shopping practices more } \\
\text { sustainable. One strategy used is to shop } \\
\text { for things that last. Consumers focused } \\
\text { then on finding quality outdoor products } \\
\text { with 'timeless design'. }\end{array}$ \\
\hline 19 & $\begin{array}{l}\text { Ku, H., Kuo, C., } \\
\text { Wu, C. \& Wu, } \\
\text { C. (2012) }\end{array}$ & 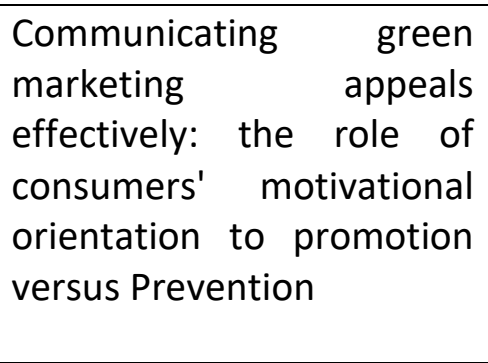 & $\begin{array}{l}\text { The individuals with a self-regulatory } \\
\text { focus on prevention reported higher } \\
\text { levels of perceived product } \\
\text { attractiveness and intention to purchase } \\
\text { when exposed to the green non- } \\
\text { product-related appeal than in response } \\
\text { to the non-green alternative. }\end{array}$ \\
\hline 20 & 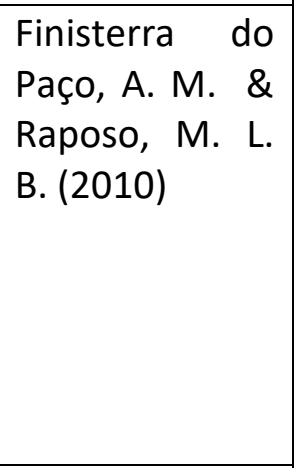 & $\begin{array}{l}\text { Green consumer market } \\
\text { segmentation: empirical } \\
\text { findings from Portugal }\end{array}$ & $\begin{array}{l}\text { Certain environmental and demographic } \\
\text { variables are significant in } \\
\text { differentiating between the 'greener' } \\
\text { consumer group and the other } \\
\text { segments. Portuguese consumers, } \\
\text { despite their support for policies } \\
\text { designed to improve the environment, } \\
\text { do not always translate their concerns } \\
\text { into environmentally friendly actions. }\end{array}$ \\
\hline 21 & $\begin{array}{lll}\text { Olson, } & \text { E. } & \text { L. } \\
(2013) & & \end{array}$ & $\begin{array}{l}\text { It's not easy being green: } \\
\text { the effects of attribute } \\
\text { tradeoffs on green product } \\
\text { preference and choice }\end{array}$ & $\begin{array}{l}\text { Although general preference is reduced } \\
\text { by tradeoffs, a green product offering } \\
\text { some compensatory advantage on a } \\
\text { conventional attribute does attract a } \\
\text { broader spectrum of consumers, while } \\
\text { only "dark green" consumers are willing } \\
\text { to pay the price to go green when the } \\
\text { product offers few compensatory } \\
\text { qualities. }\end{array}$ \\
\hline 22 & $\begin{array}{l}\text { Finisterra do } \\
\text { Paço, A. M. \& } \\
\text { Reis, R. (2012) }\end{array}$ & $\begin{array}{l}\text { Factors affecting } \\
\text { skepticism toward green } \\
\text { advertising }\end{array}$ & $\begin{array}{l}\text { The results indicate that the more } \\
\text { environmentally concerned an } \\
\text { individual is, the more skepticism he or } \\
\text { she would be toward green claims } \\
\text { exhibited on packages or featured in } \\
\text { ads. }\end{array}$ \\
\hline 23 & $\begin{array}{l}\text { Lin, Y. \& Chang, } \\
\text { C. A. (2012) }\end{array}$ & $\begin{array}{l}\text { Double standard: the role } \\
\text { of environmental } \\
\text { consciousness in green } \\
\text { product usage }\end{array}$ & $\begin{array}{l}\text { The study found that consumers } \\
\text { consider green, or environmentally } \\
\text { friendly, products to be less effective } \\
\text { than regular products; therefore, }\end{array}$ \\
\hline
\end{tabular}




\begin{tabular}{|c|c|c|c|}
\hline & & & $\begin{array}{l}\text { consumers increase the amount of the } \\
\text { green product they use to make up for } \\
\text { the perceived inferiority. }\end{array}$ \\
\hline 24 & $\begin{array}{l}\text { Rettie, R., } \\
\text { Burchell, K. \& } \\
\text { Riley, D. (2012) }\end{array}$ & $\begin{array}{l}\text { Normalizing } \quad \text { green } \\
\text { behaviours: A new } \\
\text { approach to sustainability } \\
\text { marketing }\end{array}$ & $\begin{array}{l}\text { Consumer conceptions of what is green } \\
\text { are generally consistent and correspond } \\
\text { with prevailing views on sustainability. } \\
\text { This indicates that consumers already } \\
\text { know what is green or not green, so that } \\
\text { their failure to adopt green behaviours } \\
\text { cannot just be ascribed to knowledge } \\
\text { deficit and corrected by informational } \\
\text { campaigns }\end{array}$ \\
\hline 25 & $\begin{array}{l}\text { Delong, D. \& } \\
\text { McDermott, } \\
\text { M. (2013) }\end{array}$ & $\begin{array}{l}\text { Current } r \text { perceptions, } \\
\text { prominence } r \text { And } \\
\text { prevalence of sustainability } \\
\text { in the r marketing } \\
\text { curriculum }\end{array}$ & $\begin{array}{l}\text { The findings indicate that there is a } \\
\text { presence of sustainability in the } \\
\text { curriculum, but it does not yet appear to } \\
\text { be a high priority for many institutions at } \\
\text { this time }\end{array}$ \\
\hline
\end{tabular}

\section{Methodology}

The study adopted the Survey research design. For this study, five local government areas were chosen to represent the population. The sample comprised of consumers working in different sectors of the economy. Adopting the statistical formula by Krejcie \& Morgan (1970), the sample size was 898. The multi sampling technique was adopted for this study. The research instrument that was used in this study is the questionnaire. A pilot study was carried out on 90 respondents in Ibadan, Oyo state.

\section{Results and Discussion}

Table 1 (a) Model Summary

\begin{tabular}{|l|r|r|r|r|}
\hline \multicolumn{5}{|c|}{ Model Summary } \\
\hline Model & $\mathrm{R}$ & R Square & $\begin{array}{c}\text { Adjusted R } \\
\text { Square }\end{array}$ & $\begin{array}{r}\text { Std. Error of } \\
\text { the Estimate }\end{array}$ \\
\hline 1 & $.370^{\mathrm{a}}$ & .137 & .136 & 3.15992 \\
\hline \multicolumn{5}{|l}{ a. Predictors: (Constant), green marketing } \\
\hline
\end{tabular}

Source: Field Survey, 2018

From Table 1 (a), the model summary, presents the R Square and Adjusted R Square values. The Table showed that the effect of green marketing on perceived corporate image, produced a coefficient of multiple correlation $(R)=0.370$ and a coefficient of determination $\left(R^{2}\right)=0.137$, which is significant at 0.05 level. The coefficient of multiple correlation showed that there is a low positive relationship between the independent variables and the dependent variable $(R=0.370)$. The adjusted coefficient of determination $\left(R^{2}\right)$ of 0.136 showed that green marketing explained only $13.6 \%$ of the variation in corporate image.

Table 1 (b) ANOVA 
INTERNATIONAL JOURNAL OF ACADEMIC RESEARCH IN BUSINESS AND SOCIAL SCIENCES Vol. 9, No. 7, July, 2019, E-ISSN: 2222-6990 @ 2019 HRMARS

\begin{tabular}{|c|c|c|c|c|c|c|}
\hline \multicolumn{7}{|c|}{ ANOVA $^{a}$} \\
\hline \multicolumn{2}{|c|}{ Model } & \multirow{2}{*}{\begin{tabular}{|l|}
$\begin{array}{l}\text { Sum of } \\
\text { Squares }\end{array}$ \\
1127.445
\end{tabular}} & \multirow{2}{*}{\begin{tabular}{l|}
$\mathrm{df}$ \\
\\
1 \\
\end{tabular}} & \multirow{2}{*}{$\begin{array}{l}\begin{array}{l}\text { Mean } \\
\text { Square }\end{array} \\
1127.445 \\
\end{array}$} & \multirow{2}{*}{$\begin{array}{c}F \\
112.913 \\
\end{array}$} & \multirow{2}{*}{$\begin{array}{l}\text { Sig. } \\
.000^{\mathrm{b}} \\
\end{array}$} \\
\hline \multirow{3}{*}{1} & Regression & & & & & \\
\hline & Residual & 7089.432 & 710 & 9.985 & & \\
\hline & Total & 8216.876 & 711 & & & \\
\hline
\end{tabular}

Source: Field Survey, 2018

From Table 1 (b) the F-value was 112.913 with a p-value of 0.000 indicated that the overall regression model was significant, hence, green marketing was significant in predicting perceived corporate image. Furthermore, the reported probability of $(0.000)$ was less than the conventional probability of (0.05). Therefore, green marketing has statistically significant effect on perceived corporate image.

Table 1 (c) Coefficients

\begin{tabular}{|c|c|c|c|c|c|c|}
\hline \multicolumn{7}{|c|}{ Coefficients $^{\mathrm{a}}$} \\
\hline \multirow{2}{*}{\multicolumn{2}{|c|}{ Model }} & \multicolumn{2}{|c|}{$\begin{array}{c}\text { Unstandardized } \\
\text { Coefficients }\end{array}$} & \multirow{2}{*}{$\begin{array}{c}\begin{array}{c}\text { Standardized } \\
\text { Coefficients }\end{array} \\
\text { Beta } \\
\end{array}$} & \multirow[t]{2}{*}{$\mathrm{t}$} & \multirow[t]{2}{*}{ Sig. } \\
\hline & & $B$ & Std. Error & & & \\
\hline \multirow[b]{2}{*}{1} & (Constant) & 5.006 & .367 & & 13.622 & .000 \\
\hline & $\begin{array}{l}\text { Green } \\
\text { marketing }\end{array}$ & .273 & .026 & .370 & 10.626 & .000 \\
\hline
\end{tabular}

Source: Field Survey, 2018

From Table 1 (c) the regression model showing the effect of green marketing on perceived corporate image is expressed as:

$$
\mathrm{PCl}=5.006+.273 \mathrm{GM}
$$
eq. i

where:

$\mathrm{PCl}=$ Perceive Corporate Image

$\mathrm{GM}=$ Green Marketing

In the regression equation above, when the value of green marketing is constant at zero, corporate image was 5.006. The regression coefficient of green marketing was 0.273 , which imply that an increase in green marketing by one unit leads to an increase in corporate image level by 0.273 units. Results further indicate that green marketing and corporate image had a positive and significant relationship $(\beta=0.273, p<0.05)$. Therefore, the study hypothesis $\left(H_{0}\right)$ which states that green marketing does not have significant effect on corporate image of fast moving consumer goods in Lagos state is hereby rejected.

Findings of this study is in line what results of past authors in the field of green marketing. Generally, green marketing was found to be a predictor of consumer behaviour. For example, Paço, Alves, Shiel and Filho (2013), who carried out a survey using a sample of consumers from England, Germany, 
Portugal and Spain, with the objective of developing a green consumer behavior model, tested the relationships between concepts such as man-nature orientation, generativity, environmental concern, conserving behavior and environmentally friendly buying behavior. They found that conserving behavior influences buying behavior. Giving credence to their findings is the study by Dutta (2014), who in a survey on the components of ecological behavior and consumer attitude towards sustainable green environment, found that environmental attitudes has a considerable influence on ecological behavior. In the area of green marketing and its influence of purchase decisions, Smith and Brower (2012), over a three-year period studied the green marketing strategies that influence millennials. The researchers collected and analyzed data from respondents in a behavioral lab at a major US university and found that millennials are taking note of a company's reputation, reading product labels, and looking for clues on product packaging to discern if a product is environmentally preferable. These clues are factors they consider when making purchase decisions. Likewise, the study of Karatu and Mat (2015), showed that the availability of green products has positive relationship with green purchase intention. The study also proved that environmental consciousness meditates the relationship between green price sensitivity and green purchase intention. The study concluded that the availability of green products and environmental consciousness would strongly enhance green purchase intention in Nigeria.

Fombrun, Gardberg and Barnett (2000), observed that although that corporate social and environmental performance may not directly affect a company's financial performance, it significantly affects the organizations reputational capital, which is the financial value of its intangible assets. Organizations believe that when they engage in environmental responsibility, their reputation can alleviate negative emotions from their stakeholders when faced with damaging information (Eisingerich \& Bhardwaj, 2011). Similarly, Smith, Smith, and Wang (2010), showed that a product's brand image which also involves environmental responsibility, influences corporate reputation. Firms have found particular consumer segments attractive and have strived to deliver sustainable offerings such as environmentally preferable products (Smith \& Brower, 2012). This finding was reemphasised in the work of Ko, Hwang and Kim (2013). According to the authors, corporate images are made up of three factors: social responsibility, product image, and corporate reputation. Their study showed that green marketing has a direct effect on the social responsibility and product image. Furthermore, product image and corporate reputation was found to have a direct effect on purchase intentions. In addition, according to Du, Bhattacharya and Sen (2010), corporate citizenship could help launch a positive corporate reputation thereby making consumers resistant to negative company news.

Cone (2010), averred that when an industry is viewed as a good corporate citizen, it could foster longterm, loyal relationships with consumers, who see themselves as investors in the company or brand with their purchasing power (Du, Bhattacharya, \& Sen, 2010). Corporate social responsibility activities of an organization could help improve its reputation because it establishes a social value of the company, which could help distinguish the company's product from those of its competitors (Austin, Leonard, Reficco \& Wei-Skillern, 2006). Similarly, He and Lai (2014), studied the effect of corporate social responsibility on brand loyalty. They found that consumers' perceived legal and ethical responsibilities of brands may improve brand loyalty through enhancing positive functional and symbolic images. Moreover, corporate legally responsible behavior helps to enhance a more 
functional image perceived by consumers than a symbolic image, while ethically responsible action impacts a symbolic image more than a functional image.

Chomvilailuk and Butcher (2014), in their study on the effects of quality and corporate social responsibility on loyalty, found that new social responsibility information is twice as strong a predictor as service quality while existing perceptions of socially responsible performance has a negative effect on purchase intentions. Additionally, in the work of Ammar, Naoui and Zaiem (2015), found that perceived corporate social responsibility activities have a positive and significant influence on trust toward the brand. Adopting a mixed research method D'Souza, Taghian, and Sullivan-Mort (2013), carried out a research on environmentally motivated actions influencing perceptions of environmental corporate reputation. Factor analysis and regression analysis were used to analyse data. The study findings indicate that while environmental processes are substantially important to a firm, such processes do not have a significant influence on corporate reputation. The study demonstrates that environmental marketing are significant predictors of corporate reputation.

\section{Conclusion and Recommendation}

The main objective of this study was to examine the effect of green marketing on perceived corporate image of fast moving consumer goods in Lagos State, Nigeria. The major finding of this study show that perceived corporate image of fast moving consumer goods companies in Lagos state is influenced by green marketing. Therefore, it is suggested that Fast moving consumer goods companies could develop a brand extension with products that specifically caters for some of the green concerns raised. While it has been indicated that a major problem facing green marketing is the issue of communication, it is recommended that organisations should not only engage in campaigns aimed at increasing consumers' awareness of the benefits of responding better to green marketing initiatives but also engage in campaigns aimed at minimising the appeal of environmentally unsafe products. It is recommended that for the fast moving consumer goods companies to be able to differentiate their product and brand in the highly competitive industry, they need to nurture a good corporate image by implementing green marketing and make sure it is given priority in their marketing strategies.

The study offers insights into how green marketing dimensions could be conceptualised and operationalised from the perspective of perceived corporate image. The study contributes to existing knowledge by bridging the some identified gaps in literature. The study incorporated the concept of ecological awareness to measure consumer awareness and understanding of what is 'green'. It is revealed in the study that green marketing is very crucial for improving the perceived corporate image of organisations. This supports the fundamental ideals of the legitimacy theory which states that every organisation has a moral obligation to meet the expectations of the societal members. When a company satisfies the expectations of the society, it would be viewed and treated as legitimate and vice versa. Furthermore, the study contributes to the stakeholder theory, more importantly, the normative (ethical) aspect of the theory which states that all stakeholders of an organisation must be considered and does not take into consideration, the power of each stakeholder. This study examined some key aspects of an organisation's stakeholders (consumers and environment). The study concludes that if organisations adopt right green marketing strategies which are well communicated to consumers, there will be a boost in their perceived corporate image. 
INTERNATIONAL JOURNAL OF ACADEMIC RESEARCH IN BUSINESS AND SOCIAL SCIENCES

Vol. 9, No. 7, July, 2019, E-ISSN: 2222-6990 @ 2019 HRMARS

\section{Limitations and Suggestions for Further Studies}

Although the findings of this study provide new insights into the influence of green marketing on perceived corporate image, the results may be constrained by the following issues. While this study focused on the response of just one group of the industry's stakeholders (consumers). This limited the generalizability of the findings to other stakeholders such as suppliers, industrial buyers, etc.

\section{References}

Adebanjo, D., Ojadi, F., Laosirihongthing, T. \& Tickle, M. (2013). A case study of supplier selection in developing economies: a perspective on institutional theory and corporate social responsibility. Supply Chain Management: an International Journal, 18(5), 553-566.

Ajike, E. O. (2015). Green Marketing and Consumer Buying Behaviour. A thesis submitted in Babcock University, Nigeria.

Ali, A. \& Ahmad, I. (2012). Environment friendly products: factors that Influence the green purchase intentions of Pakistani consumers. Pakistani Journal of Engineering Technology Science, 2(1), 84-117.

Ali, W. \& Rizwan, M. (2013). Factors influencing corporate social and environmental disclosure practices in the developing countries: an institutional theoretical perspective. International Journal of Asian Social Science, 3(3), 590-609.

Amaeshi, K., Adi, B., Ogbechie, C., \& Amao, O. (2006). Corporate social responsibility in Nigeria: western mimicry or indigenous influences? The Journal of Corporate Citizenship, 24, 83-99.

Amran, A. \& Susela, D. S. (2008). The impact of government and foreign affiliate influence on corporate social reporting: The case of Malaysia. Managerial Auditing Journal, 23(4), 386-404.

Austin, J. E., Leonard, D., Reficco, E. \& Wei-Skillern, J. (2006). Corporate social entrepreneurship: a new vision for CSR. The Accountable Corporation 2, 15-24.

Avetisyan, E. \& Ferrary, M. (2013). Dynamics of stakeholders' implications in the institutionalization of the CSR field in France and in the United States. Journal of Business Ethics, 115(1), 115133.

Banerjee, S. (2013). Green Marketing (Marketing Ecologically). Conference: Conference: International Conference at IMS, Ghaziabad.

Banyte, J., Brazioniene, L. \& Gadeikiene, A. (2010). Expression of green marketing developing the conception of corporate social responsibility. Engineering Economics, 21(5), 550-560

Belz, F. M. \& Peattie, K. (2009). Sustainability Marketing: A Global Perspective. Chichester: Wiley

Bhattacharyya, A. (2015). Corporate social and environmental responsibility in an emerging economy: through the lens of legitimacy theory. Australasian Accounting Business \& Finance Journal, 9(2), 79-91.

Blome, C. \& Hollos, D. (2014). Green procurement and green supplier development: antecedents and effects on supplier performance. International Journal of Production Research. 52(1), 32-49.

Bondy, K., Moon, J. \& Matten, D. (2012). An institution of corporate social responsibility (CSR) in multi-national corporations (MNCs): Form and implications. Journal of Business Ethics, 111(2), 281-299. 
INTERNATIONAL JOURNAL OF ACADEMIC RESEARCH IN BUSINESS AND SOCIAL SCIENCES

Vol. 9, No. 7, July, 2019, E-ISSN: 2222-6990 @ 2019 HRMARS

Carbone, V. \& Moatti, V. (2014). The impact of internal and external collaboration on the performance of supply chain risk management. International Journal of Logistics Systems and Management, 23(4), 534-557.

Chen, Y. S. (2010). The drivers of green brand equity: green brand image, green satisfaction, and green trust. Journal of Business Ethics, 93(2), 307-319

Chomvilailuk, R. \& Butcher, K. J. (2014). Effects of quality and corporate social responsibility on loyalty. Service Industries Journal 34(11), 938-954

Cone (2010). Cone LLC Releases the 2010 Cone Cause Evolution Study. Retrieved fromhttp://www.coneinc.com/cause-grows-consumerswant-more. Accesed 10 April, 2017

Czinkota, M., Kaufmann, H. R. \& Basile, G. (2014). The relationship between legitimacy, reputation, sustainability and branding for companies and their supply chains. Industrial Marketing Management, 43(1), 91-101.

Dann, S. \& Dann, S. (2011) Insight and Overview of Social Marketing, Government of Queensland, Australia.

Dash, S. S. \& Mishra, N. (2015). Institutional Theory as a Driver of CSR: An Integrative Framework. Interactive session.

Davari, A. \& Strutton, D. (2014). Marketing mix strategies for closing the gap between green consumers' pro-environmental beliefs and behaviours. Journal of Strategic Marketing, 22(7), 563-586.

Davis, I. (2013). How (not) to market socially responsible products: A critical research evaluation. Journal of Marketing Communications, 19(2), 1-10.

Deegan, C. \& Jeffry, U. (2006). Financial Accounting Theory. Berkshire: McGraw-Hill Education.

Delong, D. \& Mcdermott, M. (2013). Current perceptions, prominence and prevalence of sustainability in the marketing curriculum. The Marketing Management Journal, 23(2), 101116

Despeisse, M., Ball, P. D., Evans, S. \& Levers, A. (2012). Industrial ecology at factory level: aprototype methodology. Proceedings of the institution of mechanical engineers, Part B. Journal of Engineering Manufacture, 226(10), 1648-1664.

Dillard, J., Rigsby, F. \& Goodman, J. T. C. (2004). The making and remaking of organisation context: Duality and the institutionalization process. Accounting, Auditing \&Accountability Journal, 17(4), 506-542.

Doshi, V. \& Khokle, P. (2012). An institutional perspective on corporate social responsibility. Vikalpa: The Journal for Decision Makers, 37(2), 98-102.

Dowling, J. \& Pfeffer, J. (1975). Organisational legitimacy social values and organisational behaviour. Pacific Sociological Review, 18(1), 122-136.

Du, S., Bhattacharya, C. B. \& Sen, S. (2010). Maximizing business returns to corporate social responsibility (CSR): The role of social responsibility communication. International Journal of Management Reviews, 12(1), 8-19.

Dutta, S. (2014). Components of ecological behaviour and consumer attitude towards sustainable green environment: an empirical analysis on Kolkata citizens. Globsyn Management Journal, VIII(1/2), 55-69 
INTERNATIONAL JOURNAL OF ACADEMIC RESEARCH IN BUSINESS AND SOCIAL SCIENCES Vol. 9, No. 7, July, 2019, E-ISSN: 2222-6990 @ 2019 HRMARS

D’Souza, C., Taghian, M., Lamb, P. \& Peretiatko, R. (2007). Green decisions: demographics and consumer understanding of environmental labels. International Journal of Consumer Studies, 31(4), 371-376

Eccles, R. G. \& Saltzman, D. (2011). Achieving sustainability through integrated reporting. Stanford Social Innovation Review, (Summer), 56-61.

Eisingerich, A. \& Bhardwaj, G. (2011). Does social responsibility help protect a company's reputation? MIT Sloan Review Management, 52(3), 18.

Eunju K., Kyung, H. \& Young, K. (2013). Green marketing' functions in building corporate image in the retail setting. Journal of Business Research, 66(10), 1709-1715.

Fagbohun, O. (2012). Environmental degradation and Nigeria's national security: making connections. Law and Security in Nigeria, 358-383.

Fernando, S. \& Lawrence, S. (2014). A theoretical framework for CSR practices: integrating legitimacy theory, stakeholder theory and institutional theory. Journal of Theoretical Accounting, 10(1), 149-178.

Finisterra do Paço, A. M. \& Raposo, M. L. B. (2010). Green consumer market segmentation: empirical findings from Portugal. International Journal of Consumer Studies, 34, 429- 436

Finisterra do Paco, A. M. \& Reis, R. (2012). Factors affecting skeptism toward green advertising. Journal of Advertising, 41(4), 147-155

Fombrun, C. J., Gardberg, N. A., \& Barnett, M. L. (2000). Opportunity platforms and safety nets: Corporate citizenship and reputational risk. Business and Society Review, 105(1), 85-106.

Fuentes, C. (2014). Managing green complexities: consumers' strategies and techniques for greener shopping. International Journal of Consumer Studies, 38, 485-492

Gbadeyan, R. A. \& Omolekan, O. J. (2015). Relevance of green marketing on environmental degradation: an empirical study of consumers' of green products in Benin- City, Nigeria. University of Mauritius Research Journal, 21, 1-10.

González, E. M., Felix, R., Carrete, L., Centeno, E. \& Castaño, R. (2015). Green shades: a segmentation approach based on ecological consumer behavior in an emerging economy. Journal of Marketing Theory and Practice, 23(3), 25- 35.

Green, T. \& Peloza, J. (2014). Finding the right shade of green: the effect of advertising appeal type on environmentally friendly consumption. Journal of Advertising, 43(2), 128-141.

Greendex (2012). Consumer Choice and the Environment - A Worldwide Tracking Survey - Full Report. Retrieved from https://globescan.com/greendex-2012-consumer-choice-and-theenvironment-a-worldwide-tracking-survey-full-report/ Accessed 25 May, 2017

Grimmer, M. \& Woolley, M. (2014). Green marketing messages and consumers' purchase intentions: promoting personal versus environmental benefits. Journal of Marketing Communications, 20(4), 231-250.

Guo, R., Tao, L., Li, C. \& Wang, T. (2017). A path analysis of greenwashing in a trust crisis among Chinese energy companies: the role of brand legitimacy and brand loyalty. Journal of Business Ethics, 140(3), 523-536

Guo, W., Zhou, J., Yu, C., Tsai, S., Xue, Y., Chen, Q., Guo, J., Huang, P. \& Wu, C. (2015). Evaluating the green corporate social responsibility of manufacturing corporations from a green industry law perspective. International Journal of Production Research, 53(2), 665-674. 
INTERNATIONAL JOURNAL OF ACADEMIC RESEARCH IN BUSINESS AND SOCIAL SCIENCES

Vol. 9, No. 7, July, 2019, E-ISSN: 2222-6990 @ 2019 HRMARS

Hamzaoui E. L. \& Linton, J. D. (2010). New or recycled products: how much are consumers willing to pay? Journal of Consumer Marketing, 27(5), 458-468.

Harrison, R., Newholm, T. \& Shaw, D. (2005). The Ethical Consumer. London: Sage Publications.

Herrmann, A., Xia, L., Monroe, K. B. \& Huber, F. (2007). The influence of price fairness on customer satisfaction: an empirical test in the context of automobile purchases. Journal of Product \& Brand Management, 16(1), 49-58.

Horne, R. E. (2009). Limits to labels: The role of eco-labels in the assessment of product sustainability and routes to sustainable consumption. International Journal of Consumer Studies, 33(2), 175182.

Ioannou, I. \& Serafeim, G. (2010). The impact of corporate social responsibility on investment recommendations. Harvard Business School Accounting and Management Unit Working Paper No. 1507874, Boston, 11-17.

Islam, M. \& Craig, D. (2008). Motivations for an organisation within a developing country to report social responsibility information. Accounting, Auditing \& Accountability Journal, 21(6), 850-874.

Karatu, V. M. H. \& Mat, N. K. N. (2015). Predictors of green purchase intention in Nigeria: the mediating role of environmental consciousness. American Journal of Economics, 5(2), 291302.

Karmarkar, U. R. \& Bollinger, B. (2015). BYOB: how bringing your own shopping bags leads to treating yourself and the environment. Journal of Marketing, 79, 1-15

Kordshouli, E. \& Bouzanjani. (2015). An analysis of the green response of consumers to the environmentally friendly behaviour of corporations. Iranian Journal of Management Studies, 8(3), 315-334.

Kostadinova, E. (2016). Sustainable consumer behaviour: literature review. Economic Alternatives, 2, 224-234

Kronrod, A., Grinstein, A. \& Wathieu, L. (2012). Go green! Should environmental messages be so assertive? Journal of Marketing, 76, 95-102.

$\mathrm{Ku}, \mathrm{H} ., \mathrm{Kuo}, \mathrm{C} ., \mathrm{Wu}, \mathrm{C} . \& \mathrm{Wu}, \mathrm{C}$. (2012). Communicating green marketing appeals effectively. Journal of Advertising, 41(4), 41-50

Kumar, P. D. (2011). Green marketing: a start to environmental safety. Advances in Management, $4(12), 12-20$.

Kumar, U. N. \& Shree, H. N. (2018). Role of internal public in green marketing strategy. International Journal of Innovative Research in Management Studies, 2(12), 17-24.

Lawrence, T. B. \& Shadnam, M. (2008). The international encyclopedia of communication. Malden, USA: Blackwell Publishing Ltd.

Lee, S. M. \& Rha, J. S. (2013). Pressures affecting green supply chain performance. Management Decision, 51(8), 1753-1768.

Leonidou, L. C., Leonidou, C. N., Hadjimarcou, J. \& Lytovchenko, I. (2014). Assessing the greenness of environmental advertising claims made by multinational industrial firms. Industrial Marketing Management, 43(4), 671-684. 
INTERNATIONAL JOURNAL OF ACADEMIC RESEARCH IN BUSINESS AND SOCIAL SCIENCES

Vol. 9, No. 7, July, 2019, E-ISSN: 2222-6990 @ 2019 HRMARS

Leonidou, L. C., Leonidou, C. N. \& Kvasova, O. (2010). Antecedents and outcomes of consumer environmentally friendly attitudes and behaviour. Journal of Marketing Management, 26(1314), 1319-1344

Lin, Y. \& Chang, C. A. (2012). Double standard: the role of environmental consciousness in green product usage. Journal of Marketing, 76, $125-134$

Maheshwari, S. P. (2014). Awareness of Green Marketing and its Influence on buying Behaviour of Consumers: Special Reference to Madhya Pradesh, India. AIMA Journal of Management \& Research, 8(1/4), 11-21.

Mathews, M. R. (1993). Socially Responsible Accounting. London: Chapman \& Hall.

Matthes, J. \& Wonneberger, A. (2014). The skeptical green consumer revisited: testing the relationship between green consumerism and skepticism toward advertising. Journal of Advertising, 43(2), 115-127

Mayank, R. (2017). Green marketing challenges and opportunities. International Journal of Engineering and Management Sciences, 8(1), 22-33.

Miroshnychenko, I., Barontini, R. \& Testa, F. (2017). Green practices and financial performance: A global outlook. Journal of Cleaner Production, 147, 340-351.

Moraes, C., Carrigan, M., \& Szmigin, I. (2012). The coherence of inconsistencies: Attitude-behaviour gaps and new consumption communities. Journal of Marketing Management, 28(1-2), 103128.

Nyilasy, G., Gangadharbatla, H. \& Paladino, A. (2014). Perceived greenwashing: the interactive effects of green advertising and corporate environmental performance on consumer reactions. Journal of Business Ethics, 125(4), 693-707.

Ohakwe, J., Nnorom, I. C. and Iwueze, I. S. (2011). Survey of attitude of residents towards environmental deterioration in Nigeria and factors influencing their willingness to participate in reducing the trend: a case study of waste management. Trends in Applied Sciences Research, 6, 154-164.

Olamuyi, E. (2012). Preparing Nigerian Market for Green Products. National Mirrow.29/3.2013. Retrieved 7/09/2017.

Oliver, H. \& Abhishek, T. (2013) Environmental appraisal of green production systems: challenges faced by small companies using life cycle assessment. International Journal of Production Research, 51, 5884-5896

Olson, E. (2013). It's not easy being green: the effect of attribute tradeoffs on green product presence and choice. Academy of Marketing Science, 41(2), 171-184

Padhy, S. C. (2014). A study of green marketing practices in selected automobile companies and its effect on the consumers in Pune and Auragabad. Thesis Submitted to the Padmashree Dr. D.Y. Patil University

Panghal, S., Saluja, N., Dahiya, S., Khullar, P., Arya, K. \& Krishnawat, R. (2013) Green Marketing, Class presentation on green marketing, Annamalai University.

Quick Pulse Survey (2011). Retrieved from www.quick pulse: green buying - an exploration of green consumer trends. Accessed 9 April, 2017 
INTERNATIONAL JOURNAL OF ACADEMIC RESEARCH IN BUSINESS AND SOCIAL SCIENCES

Vol. 9, No. 7, July, 2019, E-ISSN: 2222-6990 @ 2019 HRMARS

Rambalak, Y. \& Govind, P. S. (2017). Determinants of consumers' green purchase behaviour in a developing nation: applying and extending the theory of planned behaviour. EcologicalEconomics, 34(C), 114-122.

Rashid, N. A. (2009). Awareness of eco-label in Malaysia's green marketing initiative. International Journal of Business and Management, 4(8), 20-26.

Rettie, R., Burchell, K. \& Barnham, C. (2013). Social normalisation: using marketing to make green normal. Journal of Consumer Behaviour, 13(1), 9-17.

Rizkallah E. G. (2012). Brand-consumer relationship and corporate social responsibility: myth or reality \&do consumers really care? Journal of Business \& Economics Research, 10(6), 333-345.

Scott, W. R. (2008). Approaching adulthood: the maturing of institutional theory. Theory and Society, $37(5), 12-19$

Scott, L. \& Vigar-Ellis, D. (2014). Consumer understanding, perceptions and behaviours with regard to environmentally friendly packaging in a developing nation. International Journal of Consumer Studies, 38(6), 642-649.

Seele, P. \& Gatti, L. (2017). Greenwashing revisited: in search of a typology and accusation-based definition incorporating legitimacy strategies. Business Strategy \& the Environment, 26(2), 239-252.

Shah, N. (2011). Green purchasing: the issue of responsible supply chain management for improving the Environmental Performance. Available at http://ebookbrowse.com/green-purchasingpdf-d19227012. Accessed: 30 may 2017

Sheikh, S. R. \& Zee R. B., (2011). Corporate social responsibility or cause-related marketing? The role of cause specificity of CSR. Journal of Consumer Marketing, 28(1), 27-39.

Singh, S. (2012). Green marketing: challenges and strategy in the changing scenario. International Journal of Advanced Research in Management and Social Sciences, 1(6), 164-173.

Smith, K.T. \& Brower, T. R. (2012). Longitudinal study of green marketing strategies that influence millennials. Journal of Strategic Marketing, 20(6), 535-551.

Smith, K. T., Smith, M., \& Wang, K. (2010). Does brand management of corporate reputation translate into higher market value? Journal of Strategic Marketing, 18(3), $201-221$.

Steffen, A. \& Gunther, S. A. (2013). Success factors of cause-related marketing: what developing countries can learn from a German sweets campaign. The MENA Journal of Business Case Studies, 2(1), 6-12.

Synovate. (2011). Retrieved from www.Synovate survey2011.com. Accessed 15 March, 2017

Tiwari, S., Tripathi, D. M., Srivastava, U., Yadav P. K. (2011). Green marketing: emerging dimensions. Journal of Business Excellence, 2(1), 20-28.

Tseng, M. L., Chiu, S. F., Tan, R. R. \& Siriban-Manalang, S. M. (2013). Sustainable consumption and production for Asia: sustainability through green design and practice. Journal of Cleaner Production, 40(2), 1-5.

UN Global Compact-Accenture's CEO Study (2010). A New Era of Sustainability. Retrieved from https://www.unglobalcompact.org/docs/news_events/8.1/UNGCAccentureCEO Study2010.pdf. Accessed 19 May, 2017

Verma, A. \& Tanwar, R. (2014). Corporate social responsibility: the next level. International Journal of Management Sciences and Business Research, 3(1), 92-106. 
Vigneau, L., Humphreys, M., \& Moon, J. (2015). How do firms comply with international sustainability standards? Processes and consequences of adopting the global reporting initiative. Journal of Business Ethics, 131(2), 469-486.

Widger, D. (2007). Green Consumer Behaviour - Part 1: Information paradox: marketing green. PJETS, 2(1) 117-125.

Wu, D. D., Olson, D. L \& Birge, J. R. (2013). Risk management in cleaner production. Journal; of Cleaner Production, 12, 16-22

Zabkar, V. \& Hosta, M. (2013). Willingness to act and environmentally conscious consumer behaviour: can prosocial status perceptions help overcome the gap? International Journal of Consumer Studies, 37(3), 257-264 